\title{
Analisis Buyback Saham Tanpa Rapat Umum Pemegang Saham pada PT Bank Mandiri, Tbk.
}

\author{
Choirun Nisful Laili \\ Fakultas Ekonomi Universitas Hasyim Asy'ari \\ email:choirunnisful@unhasy.ac.id
}

\section{Kata kunci:}

Buy back

Return

Abnormal Return

Trading Volume Activity

Keywords:

Buy back

Return

Abnormal Return

Trading Volume Activity

Choirun Nisful laili. (2020). Analisis Buyback Saham Tanpa Rapat Umum Pemegaang Saham pada PT Bank Mandiri, Tbk.. Akuntabilitas: Jurnal Ilmiah Ilmu-Ilmu Ekonomi, 13(2), $71-82$

\begin{abstract}
ABSTRAK
Penelitian ini memiliki tujuan untuk mengetahui pengaruh pengumuman buyback terhadap respon pasar pada PT. Bank Mandiri (Persero) Tbk berdasarkan Surat Edaran yang dikeluarkan OJK Nomor 3/SEOJK.04/2020 tanggal 9 Maret 2020. Penelitian ini menilai apakah terdapat perbedaan yang signifikan sebelum pengumuman buyback saham tahun 2020 dan sesudahnya terhadap return, abnormal return, dan trading volume activity saham. Objek dalam penelitian adalah PT. Bank Mandiri (Persero) Tbk. Hasil penelitian menyatakan bahwa tidak terdapat perbedaan yang signifikan sebelum dan sesudahnya pengumuman buyback saham di PT. Bank Mandiri (Persero) Tbk baik untuk return, abnormal return, dan trading volume activity sehingga dapat disimpulkan bahwa pengumuman buyback saham tahun 2020 tidak memberikan keuntungan bagi para investor.
\end{abstract}

\section{ABSTRACT}

This study aims to determine the effect of buyback announcements on market response at PT. Bank Mandiri (Persero) Tbk based on the circular issued by OJK Number 3 / SEOJK.04 / 2020 dated March 9, 2020. This study assesses whether there are significant differences before the announcement of the 2020 stock buyback and afterwards on returns, abnormal returns, and trading volume share activity. The object in this research is PT. Bank Mandiri (Persero) Tbk. The result of the research states that there is no significant difference before and after the announcement of the share buyback at PT. Bank Mandiri (Persero) Tbk is good for returns, abnormal returns, and trading volume activity, so it can be concluded that the announcement of the 2020 stock buyback is not profitable for investors.

\section{PENDAHULUAN}

Analisis Buyback Saham Tanpa Rapat Umum Pemegang Saham pada PT Bank Mandiri, Tbk. 
Capital market menjadi satu pilihan yang dapat difungsikan untuk mendapatkan pendanaan yang biayanya relatif murah bagi korporasi atau institusi lain. Pasar modal memiliki berbagai instrumen yang diperdagangkan, salah satunya yakni saham. Saham (stock) diartikan sebagai bukti kepemilikan perorangan/badan usaha dalam suatu korporasi/perseroan terbatas. Harga saham cenderung fluktuatif atau dapat berubah-ubah setiap saat, karena bursa saham pada dasarnya sangat sensitif. Suatu peristiwa yaitu peristiwa ekonomi atau non ekonomi dapat berdampak pada bursa. Peristiwa non-ekonomi yang dapat berdampak pada pergerakan bursa saham seperti halnya isu-isu yang terkait dengan hak asasi manusia, kondisi lingkungan suatu negara, demontrasi, dan aksi-aksi terorisme. Akan tetapi tidak hanya itu saja, isu politik tentang pergantian kabinet atau menteri, pemilihan presiden dan juga legislatif termasuk didalamnya. Reaksi pasar modal akan suatu peristiwa atau informasi dalam hal ini yaitu adanya wabah virus corona dilihat oleh investor melalui tinggi rendahnya harga, dari harga saham diperoleh selisih antara harga penawaran dan permintaan, yang disebut spread. Selain itu, reaksi pasar modal juga sering kali dilihat dari muncul atau tidaknya abnormal return pada indeks saham yang akan menjadi objek penelitian. Peristiwa yang memiliki kandungan informasi dapat memberikan pengaruh terhadap return saham (Serniati Zebua, 2018). mendefinisikan abnormal return yakni selisih pada return yang sesungguhnya dan return yang diharapkan.

Awal tahun 2020 tekanan yang signifikan dirasakan pada perdagangan saham di Bursa Efek Indonesia (BEI) yang ditunjukkan turunnya IHSG sebanyak 18,46 poin. Hal tersebut merupakan dampak dari melambatnya laju dan juga tekanan kondisi ekonomi, baik nasional, regional, global sebagai dampak dari wabah COVID-19 serta pelemahan yang terjadi pada harga minyak dunia. Hal ini disampaikan oleh Anto Prabowo, Deputi Komisioner Humas dan Logistik OJK, pada siaran Persnya, Senin 9/3/2020. Adanya kondisi tersebut Otoritas Jasa Keuangan (OJK) mengeluarkan kebijakan yang tertulis pada Surat Edaran OJK Nomor 3/SEOJK.04/2020 tanggal 9 Maret 2020 tentang Kondisi Lain Sebagai Kondisi Pasar yang Berfluktuasi secara Signifikan dalam Pelaksanaan Pembelian Kembali Saham yang Dikeluarkan oleh Emiten atau Perusahaan Publik. Buyback saham yang dilakukan emiten saat pasar 

dilaksanakan tanpa didahului persetujuan dalam RUPS; 2) Jumlah saham yang diperbolehkan dibeli kembali, dapat $>10 \%$ dari modal disetor dan paling banyak $20 \%$ dari modal yang disetor, dengan ketentuan yaitu paling sedikit saham yang beredar 7,5\% dari modal yang disetor Wensley et al. (1989) dalam Boudry et al (2013) menjelaskan bahwa adanya free cash flow dengan jumlah besar serta adanya pandangan tidak ada investasi yang menjanjikan bagi korporasi akan menjadi salah satu sebab dilakukan buyback saham.

PT. Bank Mandiri Tbk termasuk salah satu emiten yang melakukan buyback saham tanpa RUPS. Adanya peristiwa tersebut tentunya akan direspon secara beragam oleh market. Reaksi atas peristiwa yang terjadi dapat dilihat dari return yang merupakan nilai selisih harga, aktivitas volume perdagangan (TVA) dan juga abnormal return. Peneliti terdahulu telah banyak banyak melakukan penelitian yang serupa antara lain penelitian Andri (2013), Junizar (2013), Kurniawan (2013), Atikasari (2019), Wulan (2017), Rumapea \& Astri, (2019).

\section{METODE PENELITIAN}

Analisis data dilakukan dengan uji beda statistik parametrik paired sampel T-test dengan menggunakan data dokumentasi .

\section{Hipotesis}

$\mathrm{H}_{1}=$ Terdapat suatu perbedaan antara return sesudah dan sebelum pengumuman buyback saham tanpa RUPS pada Bank Mandiri Tbk.

$\mathrm{H}_{2}=$ Terdapat perbedaan pada abnormal return sesudah dan sebelum pengumuman buyback saham tanpa RUPS pada Bank Mandiri Tbk.

$\mathrm{H}_{3}=$ Terdapat perbedaan antara trading volume activity sesudah dan sebelum pengumuman buyback saham tanpa RUPS pada Bank Mandiri Tbk.

\section{Pengumpulan Data}

Data dokumentasi dikumpulkan secara langsung dari website resmi Bursa Efek Indonesia yaitu data seluruh saham PT. Bank Mandiri Tbk pada bulan Maret 2020. Periode pengamatan dilakukan selama 10 hari, yang dibagi menjadi 5 hari sebelum dan sesudah tanggal pengumuman, dimana terdiri dari estimate period dan window period. Untuk estimate period dimulai tanggal 04 Maret 2020 sampai dengan 14 Maret 2020. 


\section{Variabel Operasional}

1. Return Saham

Return saham yakni hasil yang didapat dari investasi saham selama periode pengamatan

\section{Abnormal Return}

Abnormal return yakni kelebihan pengembalian/penerimaan yang terjadi sesungguhnya terhadap return normal.

3. Trading Volume Activity (TVA)

TVA yaitu rasio jumlah lembar saham yang ditransaksikan dengan jumlah saham yang beredar pada periode tertentu.

\section{Analisis Data}

Uji normalitas data menggunakan Kolmogrov-Smirnov Test, kemudian uji beda dan uji hipotesis statistik parametic dengan tingkat signifikasi 0,05 meliputi analisis return, TVA dan abnormal return.

\section{HASIL DAN PEMBAHASAN}

\section{Return Saham}

Return saham diartikan sebagai pendapatan tiap lembar saham yang diperoleh dari suatu investasi. Return saham dalam penelitian ini adalah return realisasi, selisih akan harga saham periode pada saat ini dengan harga saham periode sebelumnya. Tabel 1 dan gambar 1 menunjukkan return selama periode yang diamati yaitu return sebelum dan sesudah buyback.

\section{Tabel 1}

Return Saham PT. Bank Mandiri (Persero) Tbk

\begin{tabular}{|c|c|c|c|}
\hline Event Period & Sebelum & Event Period & Sesudah \\
\hline-5 & -0.04467 & 1 & 0.045627 \\
\hline-4 & 0.035971 & 2 & -0.00727 \\
\hline-3 & 0.038194 & 3 & -0.05861 \\
\hline-2 & 0.016722 & 4 & -0.01167 \\
\hline-1 & -0.04605 & 5 & 0 \\
\hline Mean & 0,0000324 & Mean & $-0,0063853$ \\
\hline
\end{tabular}




\begin{tabular}{|c|c|c|c|}
\hline Event Period & Sebelum & Event Period & Sesudah \\
\hline Std.Deviation & 0,04227573 & Std.Deviation & 0,03708792 \\
\hline
\end{tabular}

Sumber: Data Diolah, 2020

Tabel 1 menunjukan rata-rata return saham PT.Bank Mandiri Tbk. sebelum pengumuman sebesar 0,0000324 dan sesudah pengumuman sebesar -0,0063853. Dari deskripsi di atas dapat diamati bahwa return rata-rata sebelum buyback tersebut lebih besar nilainya daripada rata-rata return sesudah peristiwa. Hal ini menunjukkan bahwa terdapat fluktuasi harga saham lebih tinggi sebelum daripada sesudah terjadi pengumuman buyback saham tahun 2020. Tampak pada periode ini bahwa semua investor lebih berhati-hati dalam melakukan pembelian saham, serta masih adanya keraguan di kalangan para investor terhadap pengumuman buyback, hal ini juga dapat dijadikan sebagai indikasi bahwa masih terdapat keraguan di kalangan investor terhadap pelaksanaan buyback saham. Bila dibandingkan dengan periode sebelum buyback, terjadi penurunan return yang dihasilkan sebesar -0,00641779. Penurunan return saham ini diduga disebabkan banyaknya pelaku pasar yang melepaskan sahamnya, dan menyebabkan harga saham sedikit mengalami koreksi. Karena adanya berita-berita tertentu yang dapat memicu kepanikan di bursa atau saham sehingga mendorong investor untuk melepas sahamnya. Diperoleh standard deviasi yang menunjukkan besarnya penyimpangan nilai data sebelum dan sesudah buyback terhadap returnnya, sebesar 0,04227573 dan 0,03708792, hal ini menunjukkan nilai return saham pada masa sebelum buyback memiliki deviasi yang lebih besar dari pada sesudah buyback dengan beda yang relatif tipis, hasil ini menunjukkan nilai data return saham relatif tidak terlalu bervariasi, sehingga menyebabkan deviasinya retalif tidak terlalu besar terhadap nilai return yang diperoleh oleh saham yang diamati di sekitar hari buyback berlangsung. Pada gambar 1 return saham selama 5 hari sebelum pengumuman buyback menunjukkan fluktuasi, kenaikan paling tajam adalah pada hari -3, dimana memiliki nilai kenaikan sebesar -0,002223 bila dibandingkan dengan hari sebelumnya. Fluktuasi yang terjadi sebelum buy back berlangsung disebabkan oleh preferensi yang beragam terhadap pengumuman buy back tersebut. Pada periode setelah dilaksanakannya buyback atau hari ke +1 buyback, 
return saham yang didapat mengalami fluktuasi, penurunan paling tajam terjadi pada hari ke +3 dan ditutup dengan kenaikan pada hari ke +5 .

\section{Gambar 1}

\section{Grafik Return Saham PT. Bank Mandiri (Persero) Tbk}

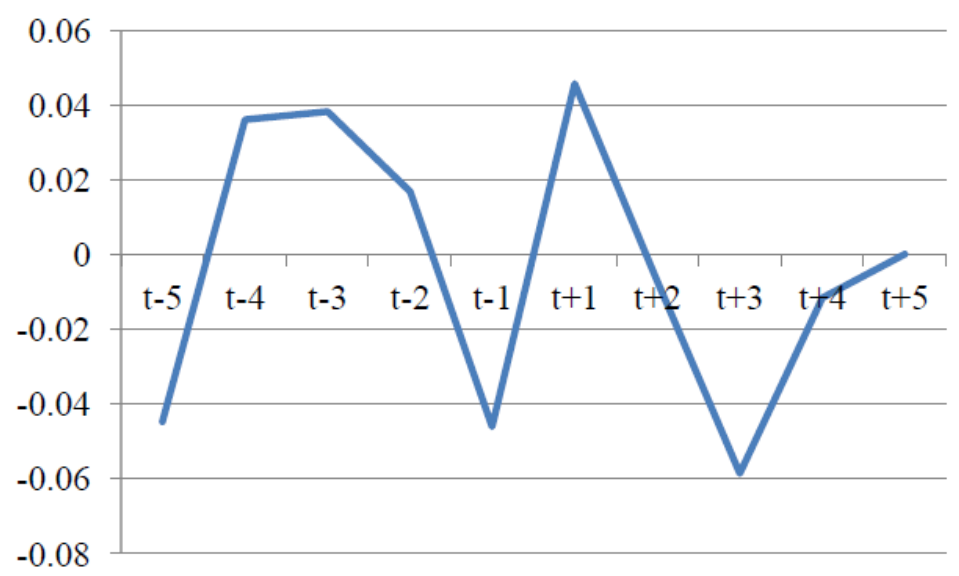

Sumber: Data Diolah, 2020

Hasil uji statistik Return Saham PT.Bank Mandiri Tbk sebagai berikut :

Tabel 2

Hasil Uji Statistik Return Saham PT.Bank Mandiri Tbk Sebelum Dan Sesudah Pengumuman Buyback

\begin{tabular}{|c|c|}
\hline d.f & 9 \\
\hline$t_{\text {hitung }}$ & 0,193 \\
\hline$t_{\text {tabel }}\left(\frac{\alpha}{2} ; \mathrm{n}-1\right)$ & 2,2622 \\
\hline Asymp.Sig.(2-tailed) & 0,856 \\
\hline Keterangan & Tidak Signifikan \\
\hline
\end{tabular}

Sumber : Data diolah, 2020

Pada tabel 2 tercatat thitung 0,193 berada di dalam penerimaan $H_{0}\left(-\mathrm{t} \frac{\alpha}{2} ; n-1\right)<t($ $\left.\frac{\alpha}{2} ; n-1\right)$ t karena $-2,2622<0,193<2,2622$. Sehingga dapat diambil keputusan menerima $H_{0}$, menolak $H_{1}$. Berdasarkan nilai probabilitasnya Asymp.Sig.(2-tailed) dimana nilai probabilitasnya 0,856 $>0,05$ maka $H_{0}$ diterima dan $H_{1}$ ditolak. Dari dua hal di atas maka dapat disimpulkan jika return saham PT. Bank Mandiri Tbk tidak mendapati perbedaan yang terbilang signifikan antara sebelum dan sesudah 
terhadap return saham ini sejalan dengan hasil penelitian Kurniawan, (2013), Wulan et al (2017), Kurniawan (2019), Rumapea \& Astri (2019)

\section{Abnormal Return}

Apabila suatu peristiwa mengandung informasi di luar harapan para pelaku pasar, maka nilai keseimbangan harga akan kembali berfluktuasi yang kemudian membentuk harga keseimbangan yang baru. Indikasi terdapatnya informasi atau tidaknya ditunjukkan dengan perolehan abnormal return atau tingkat keuntungan yang lebih besar dari harapan pasar.

Tabel 3

Grafik Abnormal Return PT. Bank Mandiri (Persero) Tbk

\begin{tabular}{|c|c|c|c|}
\hline Event Period & Sebelum & Event Period & Sesudah \\
\hline-5 & -0.041249 & 1 & 0.048885 \\
\hline-4 & 0.039163 & 2 & -0.003868 \\
\hline-3 & 0.041414 & 3 & -0.055015 \\
\hline-2 & 0.020073 & 4 & -0.008345 \\
\hline-1 & 0.020073 & 5 & 0.003563 \\
\hline Mean & 0,00336278 & Mean & $-0,00295627$ \\
\hline Std.Deviation & 0,04216190 & Std.Deviation & 0,03697985 \\
\hline
\end{tabular}

Sumber : Data diolah, 2020

Tabel tersebut mencatat bahwa rata-rata untuk abnormal return saham sebelum buyback sebesar 0,00336278 sedangkan sesudah buyback sebesar -0,00295627. Dapat dilihat bahwa terjadi penurunan nilai sebelum dan sesudah buyback. Ini juga menunjukkan bahwa investor cenderung berhati-hati dalam memutuskan untuk membeli saham dan investor mempunyai preferensi beragam terhadap pelaksanaan buy back saham tersebut. Diperoleh standard deviasi yang menunjukkan besarnya penyimpangan nilai data sebelum dan sesudah buyback terhadap abnormal returnnya, sebesar 0,04216190 dan 0,03697985, hal ini menunjukkan nilai abnormal return saham pada masa sebelum buyback memiliki deviasi yang lebih besar dari pada sesudah buy back dengan beda yang relatif tipis. 
Hasil ini menunjukkan nilai data abnormal return saham relatif tidak terlalu bervariasi, sehingga menyebabkan deviasinya relatif tidak terlalu besar terhadap nilai abnormal return yang diperoleh oleh saham yang diamati di sekitar hari buy back berlangsung.

\section{Gambar 2}

\section{Grafik Abnormal Return PT. Bank Mandiri (Persero) Tbk}

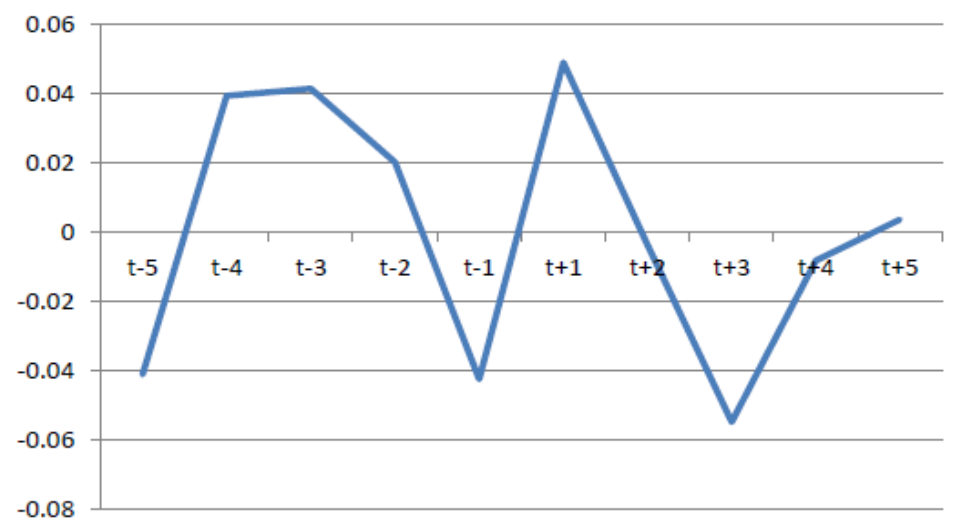

Sumber : Data diolah, 2020

Pada gambar diatas, abnormal return terjadi penurunan yang paling tajam terjadi pada hari -1 dan meningkat cukup tajam pada hari ke+1, kembali berfluktuasi dengan kecenderungan turun yang cukup tajam pada hari ke +3 , serta ditutup dengan kenaikan pada hari ke +4 .

\section{Tabel 4}

\section{Hasil Uji Statistik Abnormal Return PT.Bank Mandiri Tbk Sebelum Dan Sesudah}

Pengumuman Buyback

\begin{tabular}{|c|c|}
\hline d.f & 9 \\
\hline$t_{\text {hitung }}$ & 0,190 \\
\hline$t_{\text {tabel }}\left(\frac{a}{2} ; \mathrm{n}-1\right)$ & 2,2622 \\
\hline Asymp.Sig.(2-tailed) & 0,858 \\
\hline Keterangan & Tidak Signifikan \\
\hline
\end{tabular}

Sumber : Data diolah, 2020

Tabel 4 diatas menunjukkan arti bahwa 0,190 berada dalam daerah penerimaan $H_{0}(-\mathrm{t}$ $\left.\frac{\propto}{2} ; n-1\right)<t\left(\frac{\propto}{2} ; n-1\right) \mathrm{t}$ karena $-2,2622<0,190<2,2622$. Oleh karenanya $H_{0}$ dapat diterima dan $\mathrm{H}_{2}$ ditolak. Jika diamati dari nilai probabilitasnya Asymp.Sig.(2-tailed) 

ditolak. Sehingga abnormal return saham PT. Bank Mandiri Tbk dinyatakan tidak menunjukkan perbedaan signifikan sebelum pengumuman buyback dan sesudah pengumuman buyback saham tahun 2020. Hal ini sejalan dengan hasil penelitian Kurniawan (2019) yang menyebutkan bahwa tidak ada perbedaan yang signifikan untuk abnormal return.

\section{Trading Volume Activity}

Pengukuran variabel ini dilihat dari data TVA perusahaan dihitung secara harian, yakni 5 hari sebelum, 1 hari pada hari pengumuman dan 5 hari setelahnya. Tabel 3 di bawah ini menunjukkan rata-rata untuk trading volume activity saham sebelum buyback sebesar 0,00101214 sedangkan sesudahnya sebesar 0,00117191. Hal ini menunjukkan bahwa terjadi kecenderungan peningkatan yang relatif kecil sebelum dan sesudah buy back. Diperoleh standard deviasi yang menunjukkan besarnya penyimpangan nilai data sebelum dan sesudah buyback terhadap trading volume activitynya, sebesar 0,00013795 dan 0,00092388, hal ini menunjukkan nilai trading volume activity saham pada masa sebelum buyback memiliki deviasi yang lebih kecil dari pada sesudah buy back dengan beda yang relatif tipis.

Tabel 5

Trading Volume Activity Saham PT. Bank Mandiri (Persero) Tbk

\begin{tabular}{|c|c|c|c|}
\hline Event Period & Sebelum & Event Period & Sesudah \\
\hline-5 & 0.001099 & 1 & 0.001234 \\
\hline-4 & 0.001044 & 2 & 0.001052 \\
\hline-3 & 0.001002 & 3 & 0.000991 \\
\hline-2 & 0.001134 & 4 & 0.002583 \\
\hline-1 & 0.000783 & 5 & 0 \\
\hline Mean & 0,00101214 & Mean & 0,00117191 \\
\hline Std.Deviation & 0,00013795 & Std.Deviation & 0,00092388 \\
\hline
\end{tabular}

Sumber : Data Diolah, 2020

Grafik pada gambar 3 tersebut, menunjukkan hasil yang berfluktuasi. Hari ke -1 mengalami penurunan dan kembali berfluktuasi dengan kecenderungan naik pada hari ke +1 , serta ditutup dengan kenaikan yang cukup tajam pada hari ke +4 dengan 
nilai trading volume activity sebesar 0.002583 . Hal yang bisa diamati di sini adalah mengenai kenaikan maupun penurunan trading volume activity tersebut relatif tipis.

\section{Gambar 3}

\section{Grafik Trading Volume Activity Saham PT. Bank Mandiri (Persero) Tbk}

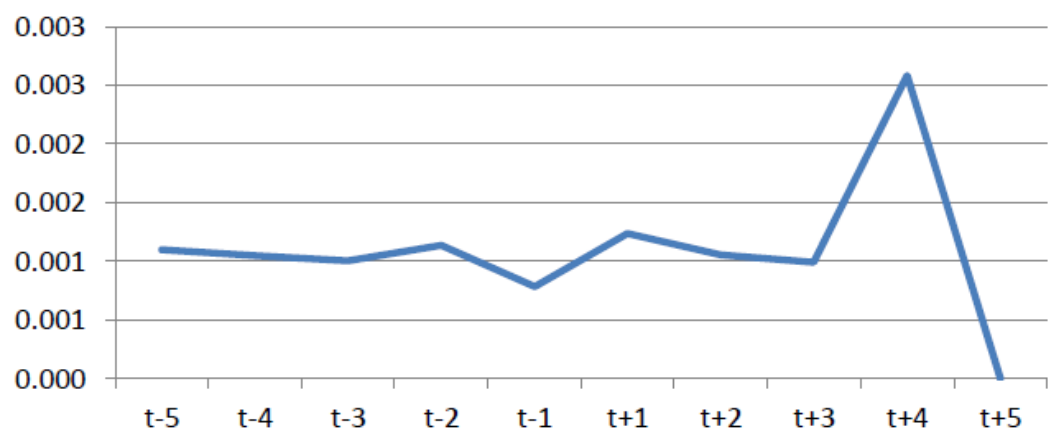

Sumber : Data Diolah, 2020

Tabel berikut menunjukkan hasil pengujian statistik TVA PT.Bank Mandiri Tbk

Tabel 6

\section{Hasil Uji Statistik Trading Volume Activity PT.Bank Mandiri Tbk Sebelum Dan} Sesudah Pengumuman Buyback

\begin{tabular}{|c|c|}
\hline d.f & 9 \\
\hline$t_{\text {hitung }}$ & $-0,443$ \\
\hline$t_{\text {tabel }}\left(\frac{a}{2} ; \mathrm{n}-1\right)$ & 2,2622 \\
\hline Asymp.Sig.(2-tailed) & 0,681 \\
\hline Keterangan & Tidak Signifikan \\
\hline
\end{tabular}

Sumber : Data diolah, 2020

Tabel diatas menunjukkan arti bahwa -0,443 berada di dalam daerah penerimaan $H_{0}$ $\left(-\mathrm{t} \frac{\alpha}{2} ; n-1\right)<t\left(\frac{\alpha}{2} ; n-1\right) \mathrm{t}$ karena $-2,2622<-0,443<2,2622$. Sehingga dapat diputuskan $H_{0}$ diterima dan $H_{3}$ ditolak. Berdasarkan dari nilai probabilitasnya Asymp.Sig.(2-tailed) dimana nilai probabilitasnya 0,681 > 0,05 maka diputuskan untuk menerima $H_{0}$ dan menolak $H_{3}$. Dapat ditarik kesimpulan bahwa trading volume activity saham PT. Bank Mandiri Tbk tidak berbeda signifikan sebelum dan sesudahnya pengumuman buyback saham tahun 2020.

Hasil pengujian yang dilakukan menyatakan tidak terdapat adanya perbedaan antara return sebelum dan sesudahnya pengumuman buyback saham di Analisis Buyback Saham Tanpa Rapat Umum Pemegang Saham pada PT Bank Mandiri, Tbk. 
PT. Bank Mandiri (Persero) Tbk. Untuk abnormal return sebelum dan sesudahnya pengumuman buyback tidak adanya perbedaan yang signifikan. Untuk TVA juga tidak ditemukan perbedaan yang tercatat signifikan, dapat disimpulkan bahwa pengumuman buyback saham tahun 2020 tidak memberikan keuntungan bagi para investor. Hal ini tidak sesuai dengan temuan Saragih (2015).

\section{KESIMPULAN}

1. Tidak ada perbedaan yang terbilang signifikan pada return saham periode sebelum pengumuman buyback dan sesudah terjadinya pengumuman buyback saham 2020. Hasil ini berarti bahwa tindakan spekulatif yang dilakukan investor cukup mempengaruhi fluktuasi harga saham PT. Bank Mandiri Tbk.

2. Tidak terdapat perbedaan secara signifikan antara abnormal return ( $A R$ ) selama periode pengamatan antara sebelum pengumuman buyback dan sesudahnya pengumuman. Hasil ini berarti bahwa investor belum memperoleh keuntungan sesuai ekspektasi dari investasi yang dilakukan karena ketidakpastian fluktuasi harga sebelumnya dan juga berarti bahwa tidak terdapat adanya informasi yang lebih guna membantu investor mendapatkan abnormal return yang mendorong mereka untuk mendapatkan return yang lebih.

3. Tidak ada suatu perbedaan secara signifikan pada TVA periode sebelum terjadi pengumuman buyback saham tahun 2020 dan sesudahnya. Hasil ini menandakan bahwa investor di Indonesia tidak terlalu merespon cepat atas informasi yang diterima atau investor menganggap bahwa pengumuman buyback saham tahun 2020 bukan berarti good news.

\section{Saran}

1. Investor

Pada pengambilan keputusan hendaknya investor tidak saja hanya meninjau peristiwa pengumuman buyback saham, akan tetapi harus mencermati beberapa faktor lainnya. Sehingga informasi yang diterima dapat digunakan untuk mempertimbangkan tindakan yang akan diambil di masa mendatang.

2. Peneliti selanjutnya 
Peneliti selanjutnya yang tertarik untuk meneliti fenomena buyback saham sebaiknya dapat didukung wawancara dengan praktisi pasar modal agar menambah data primer dengan tujuan mendapat informasi yang lebih banyak dan akurat seputar buyback saham, selain itu ide penambahan periode pengamatan juga dapat dipilih agar mendapatkan hasil yang lebih signifikan.

\section{DAFTAR PUSTAKA}

Boudry, W. I., Kallberg, J. G., \& Liu, C. H. (2013). Investment opportunities and share repurchases. Journal of Corporate Finance, 23, 23-38.

https://doi.org/10.1016/j.jcorpfin.2013.07.006

Junizar, M. L. (2013). Pengaruh Pengumuman Pembelian Kembali Saham (Buy Back) Terhadap Respon Pasar: Studi Pada Perusahaan Yang Terdaftar Di Bursa Efek Indonesia (Bei). Skripsi, 539-549.

Kurniawan, M. Z. (2013). Performance Analysis of Companies Go Public in Indonesia Doing Stock Buyback Policy. European Journal of Business and Management, 5(22), 163-170. http://www.iiste.org/Journals/index.php/EJBM/article/view/7466

Kurniawan, Moh. Zaki. (2019). Analisis Kinerja Saham LQ-45 Pada PILKADA DKI Jakarta Putaran II 2017. AKUNTABILITAS: Jurnal Ilmiah Ilmu-Ilmu Ekonomi, 12(2), 87-96. https://doi.org/10.35457/akuntabilitas.v12i2.932

Rumapea, \& Astri. (2019). ANALISIS PENGARUH STOCK BUYBACK TERHADAP HARGA SAHAM DAN RETURN SAHAM PADA PERUSAHAAN YANG TERDAFTAR DI BURSA EFEK INDONESIA. Jurnal Akuntansi Dan Keuangan Metodist, 2 Nomor 2,(9), 164-174.

Saragih, A. E. (2015). Pengaruh pengumuman pembelian kembali saham. Jurnal Akuntansi, 1(2), 115-139.

Serniati Zebua. (2018). PENGARUH PENGUMUMAN DIVIDEN TERHADAP RETURN SAHAM DI BURSA EFEK INDONESIA. Skripsi.

Wulan, D. R., Brawijaya, U., Administrasi, F. I., Ilmu, J., Bisnis, A., Studi, P., Bisnis, A., \& Keuangan, K. M. (2017). Aktivitas perdagangan saham sebelum dan sesudah pengumuman stock buyback. Skripsi.

dan C. H. Liu. (2013). Investment Opportunities and Buyback. Journal of Corporate Finance, 23 (23-38)

Darmadji, T., \& Hendy, M. (2012). Fakhruddin. Pasar Modal Di Indonesia. Edisi Ketiga. Salemba Empat. Jakarta.

Jogiyanto, H. (2014). Teori Portofolio dan Analisis Investasi, Edisi Kesembilan. BPEF. Yogyakarta.

Surat Edaran OJK Nomor 3/SEOJK.04/2020 